\title{
Lighting Design Analysis in an Industrial Workshop Space: Case Study at Jakarta Creative Hub Workshop Space
}

\author{
Khalid Abdul Mannan ${ }^{1}$ \\ ${ }^{1}$ Department of Architecture, Institut Teknologi dan Bisnis Kalbis, Jakarta, \\ Indonesia
}

\author{
Article History \\ Received : 28 October 2020 \\ Accepted : 27 December 2020 \\ Published : 24 April 2020
}

\begin{abstract}
The existence of light is one of the requirements for the continuity of human productivity, where human activity requires light to see. Visual comfort of workers in the industry affects their productivity levels, especially in human-based industries where humans need maximum light intensity to do work according to the level of complexity. This paper examines the lighting condition in the fashion workshop room at the Jakarta Creative Hub, to find out whether the lighting in the area is following national lighting standards for industrial areas or not. The study was carried out by a direct measurement method with a lux meter to determine the level of light intensity and simulation with software Dialux to find new lighting design alternatives. The result gathered from this study is the type and placement of light points in the Jakarta Creative Hub fashion workshop area that meets Indonesian national standards for lighting in industrial areas.
\end{abstract}

Keywords: lighting, visual comfort, industry, workshop area

\section{Introduction}

Visual comfort is related to natural light, which helps humans in accessing visual information without disturbing the human visual senses (Manurung, 2012). Visual comfort is generally related to the intensity of light around it. Visual comfort related to work productivity in the previous study shows that a room with good lighting conditions can increase the productivity of people working in it (Padmanaba, 2006).

Visual comfort standards for rooms are calculated in lux quantities. Concerning space, the type of human activity that takes place in the space will affect the level of lighting needs. Human activity is related to bodily movements and the use of the five senses. A sense of sight is needed to help the organization of activities in a room to run well (Karyono, 2016). Visual comfort can be achieved if the points of visual

Correspondence: Khalid Abdul Mannan

Department of Architecture, Institut Teknologi dan Bisnis Kalbis

E-mail: khalidabdulmannan@gmail.com comfort are applied optimally, including the suitability of the design to the recommended light standards and the layout of the room following the distribution of lighting (Widiyantoro et.al., 2017).

Indonesia with sun-rich conditions throughout the year should place natural lighting as a priority in the design; Aside from being an environmental response effort, its utilization can also save building energy consumption (Thojib \& Adhitama, 2013). With appropriate lighting, our activities will not be interrupted (Setiawan A., 2013).

In the industrial world, the standard for lighting uses the Indonesian National Standard for energy conservation in lighting systems, which is compared to the health standards and requirements of the industrial work environment. To meet the level of lighting in a room following the standards, it needs to consider the location and orientation of the building, the shape, size, and orientation of the window (Sushanti et.al., 2015). 
Lighting Design Analysis in an Industrial Workshop Space: Case Study at Jakarta Creative Hub Workshop Space Khalid Abdul Mannan
Jakarta Creative Hub itself is a business incubator in the Creative Industry field, which was established by the DKI Jakarta government, located in Tanah Abang, Central Jakarta. It has a seminar room area, a meeting room, and a workshop room for training activities, and there is a business space that can be used by selected SMEs to have an office in that area.

This study took the case study in the workshop area or also called makerspace at the Jakarta Creative Hub. Selection of the Jakarta Creative $\mathrm{Hub}$ as a research location due to its function as a creative industry incubator. It is expected that the analysis of lighting design in the workshop area can be a reference for other workshop area lighting designs to function optimally for industries, especially creative industries based on workshops and craftsmanship.

The main problem of this research is to identify for differences between the real conditions of the workshop lighting with the standard lighting requirements needed for the workshop space. It is then examined to find lighting design solutions that can answer the lighting needs for the visual comfort of people working in the workshop area.

\section{RESEARCH METHODS}

This study uses a quantitative thinking framework in which there is a dependent variable that is simulated and tested with software (Dialux) to get the value or expected results. Like previous research, the method used is an experimental method using simulation with Dialux 4.12 software to find out design strategies that can optimize the performance of natural lighting (Rahmadiina et.al., 2017).

This study will focus on the relationship between visual comfort and the level or magnitude of lighting values so that other variables related to visual comfort in this study will be considered as non-existent.

Data collection methods used are through case studies and literature studies, as well as direct measurements and simulations. Literature studies are obtained through books and journals related to research topics. In general, this research is divided into two stages of research with different methods. The first stage is the method of observation, which is accompanied by measuring the intensity of light in the location studied, while the second stage is to use the simulation method.

The first stage is an observation which performed to map the activities nodes inside the Jakarta Creative Hub workshop room. Furthermore, from the activity map, measurements were taken to determine whether the available light intensity had met the requirements for the visual comfort of the space used or not. The tool used is Lux meter, which is useful for gathering the level of light illumination in the measured area.

The second stage is to carry out the lighting simulation process with Dialux software to get an alternative lighting design. The simulation is done with the initial hypothesis that there are differences in the level of illumination of lighting in the current workshop space with the standard requirements for visual comfort requirements of the workshop space. The result is an alternative lighting design that fits the visual comfort requirements of the workshop area, especially for the Jakarta Creative Hub workshop area.

Figure 1. Research thinking framework

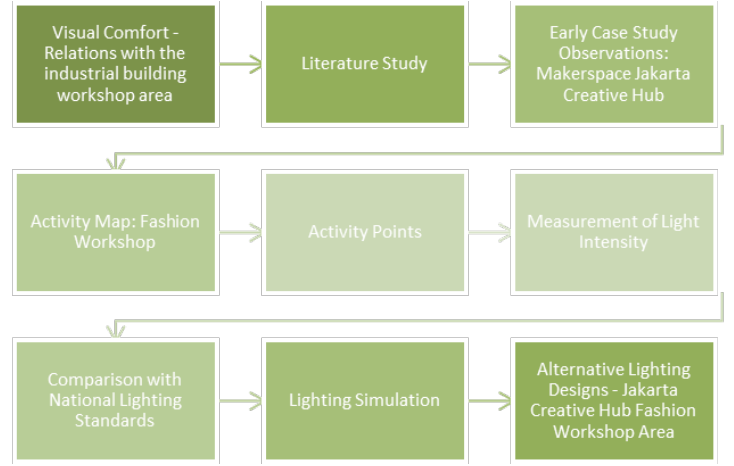

From previous studies, it is known that numerical calculations based on SNI are carried out as the basis of lighting system design, simulations are carried out to obtain optimal calculations, and evaluation of lighting systems is carried out by direct measurements in the field (Ardiyanto et.al., 2014).

\section{LITERATURE REVIEW}

\section{A. Visual Comfort}

Visual comfort is comfort in accessing all visual information and is related to the sense of sight. The purpose of planning a lighting system is to 
optimize the lighting in a room so that human activities are not disturbed. Lighting systems can be done in 2 (two) ways, namely naturally and artificially (Widiyananto, nd.). Visual comfort is determined by intense illumination of the lighting level, color quality (color rendering), and level of blinding (Latifah et.al., 2013).

Visual comfort parameters are as follows:

1. Illumination

The measured lighting must meet the minimum requirements according to the standard. The heavier the visual work, the higher illumination is needed. If natural lighting does not meet the requirements, the addition of artificial lighting is required.

2. Luminance

The luminance in the object should not generate light contrast and or excessive brightness; hence the glare index occurs under the needs of a visual work that does not give the effect of glare in the eye.

3. Color quality The color produced by the light source (color temperature) and the color is seen from the object (color rendering) must be following the atmosphere related to psychology and the activity or function accommodated by the space (Latifah, 2015).

\section{B. Natural Lighting}

Natural lighting is lighting obtained from direct sunlight, where the light is obtained in the morning until the afternoon. Natural light, in general, is divided into two, namely Sunlight and Daylight. Sunlight is the light of direct sunlight that must be maintained so that the numbers remain in control to avoid glare and solar radiation. Daylight is indirect sunlight in the form of diffuse or reflection from the sky. This type of solar light is used for lighting and environmental health because solar heat does not transmit directly into the building (Handoko, nd). Utilization of natural light is emphasized during the day, so the use of artificial lighting can be minimized (Sutantri et.al., 2015).

Daytime natural lighting is good if: 1.) During the day between 08.00 and 16.00 local time, there is enough light entering the room. 2.) The distribution of light in the room is fairly even and or does not cause disturbing contrast (Handoko, nd.) The role of lighting is no longer just providing lighting but also emphasizes the aesthetics and atmosphere of the room. It can even affect the interior image (Hadianto et.al.,2013).
Based on the technique, natural lighting is divided into two:

\section{Passive Technique}

The technique uses natural light for lighting in a room or building with the design of light openings on the skin or envelope of the building (Latifah, 2015).

2. Active Techniques

The technique utilizes natural light for lighting in a room/building with the help of lighting systems installed in the building (Latifah, 2015).

\section{Artificial Lighting}

Artificial lighting is lighting that is produced from a light source other than natural light. With the development of civilization and technology, humans created artificial lighting. Initially, artificial lighting as a substitute for natural sunlight, then artificial light obtained from fire, then research and development of light bulbs by Alessandro Volta, Sir Humphry Davy, Warren De La Rue, to Thomas Alva Edison (Setiawan \& Hartanti, 2014).

Artificial lighting is needed in the inner and outer spaces of buildings related to the design of facades that tend to be massive, the depth of space in the building, substitute for sunlight, and the lack of natural lighting that enters the room (Latifah et.al., 2013). Artificial lighting is divided into several types, namely:

- General Lighting (General/Overall lighting)

- Accent Lighting (Special lighting/details)

- Task Lighting (Lighting work activities)

- Decorative Lighting (Decorative Lighting)

Lighting conditions that have not been maximized can be optimized through changes in the type, location, amount, and color of artificial lighting (Soegandhi et.al., 2015).

\section{Glare}

Glare is a "visual disturbance" that affects visual performance. There are two types of glare, namely direct and reflection, each of which can have a detrimental effect on the ability to see (Lechner, 2007). A direct sunlight barrier is needed to avoid this, such as providing a corridor next to the building, making a drained roof or making fins on a window. The principle of protection against direct sunlight is the filtering of light or the creation of shadows. To avoid the glare of sunlight can also be done by using colored or coated glass that has the ability to absorb or reflect sunlight (Frick et.al.,2008). 
Lighting Design Analysis in an Industrial Workshop Space: Case Study at Jakarta Creative Hub Workshop Space Khalid Abdul Mannan

\section{E. Visual Comfort Standard}

Visual Comfort Standards for lighting each room needs a different visual comfort according to the type of activity carried out. The higher the level of complexity of the activities carried out, the higher the level of lighting needed. As a comparison later whether the workshop room in the Jakarta Creative Hub has met visual comfort standards for work or not, the following is a standard table of lighting levels needed in conjunction with space functions, cited from the Indonesian National Standard for Energy Conservation in Lighting Systems (SNI, 2017).

Figure 2. The Indonesian National Standard for Energy Conservation in Lighting Systems has to do with the function of space in industrial buildings

\begin{tabular}{|c|c|c|c|c|c|}
\hline \multirow[b]{2}{*}{ Fungsi ruangan } & \multirow{2}{*}{$\begin{array}{c}\text { Tingkat } \\
\text { pencahayaan } \\
(L u x)\end{array}$} & \multirow{2}{*}{$\begin{array}{c}\begin{array}{c}\text { Kelompok } \\
\text { renderasi } \\
\text { warna }\end{array} \\
\end{array}$} & \multicolumn{3}{|c|}{ Temperatur warna } \\
\hline & & & $\begin{array}{c}\text { Warm white } \\
<3300 \mathrm{~K}\end{array}$ & $\begin{array}{c}\text { Cool white } \\
3000 \mathrm{~K}-5300 \mathrm{~K}\end{array}$ & $\begin{array}{l}\text { Dayllght } \\
>5300 \mathrm{~K}\end{array}$ \\
\hline \multicolumn{6}{|l|}{ Perkantoran: } \\
\hline Ruang Direktur & 350 & 1 atau 2 & & + & - \\
\hline Ruang kerja & 350 & 1 atau 2 & & - & + \\
\hline Ruang komputer & 350 & 1 atau 2 & & + & $\cdot$ \\
\hline Ruang rapat & 300 & 1 & - & + & \\
\hline Ruang gambar & 750 & 1 atau 2 & & + & + \\
\hline Gudang arsip & 150 & 1 atau 2 & & - & + \\
\hline Ruang arsip aktif & 300 & 1 atau 2 & & + & - \\
\hline \multicolumn{6}{|l|}{ Industri (Umum): } \\
\hline $\begin{array}{l}\text { Gudang } \\
\end{array}$ & 100 & 3 & & - & $\cdot$ \\
\hline Pekerjaan kasar & $100-200$ & 2 atau 3 & & + & + \\
\hline Pekerjaan menengah & $200-500$ & 1 atau 2 & & $\cdot$ & • \\
\hline Pekerjaan halus & $500-1000$ & 1 & & $\cdot$ & $\cdot$ \\
\hline Pekerjaan amat halus & $1000-2000$ & 1 & & $\cdot$ & $\cdot$ \\
\hline Pemeriksaan warna & 750 & 1 & & $\cdot$ & $\cdot$ \\
\hline \multicolumn{6}{|l|}{ Rumah ibadah: } \\
\hline Masjid & 200 & 1 atau 2 & & . & \\
\hline Gereja & 200 & 1 atau 2 & & $\cdot$ & \\
\hline Vinara & 200 & 1 atau 2 & & + & \\
\hline
\end{tabular}

\section{RESULTS AND DISCUSSION}

The Jakarta Creative Hub workshop room area is divided into three parts, namely the fashion workshop area, the 3D printing workshop area, and the wood and metal workshop area. Each workshop area is divided based on the specificity of their respective uses. This study will focus on discussing the area of the fashion workshop at the Jakarta Creative Hub. The general description of the distribution of the fashion workshop area in Jakarta Creative Hub can be seen in the following picture:
Figure 3. Division of workshop area at Jakarta Creative Hub

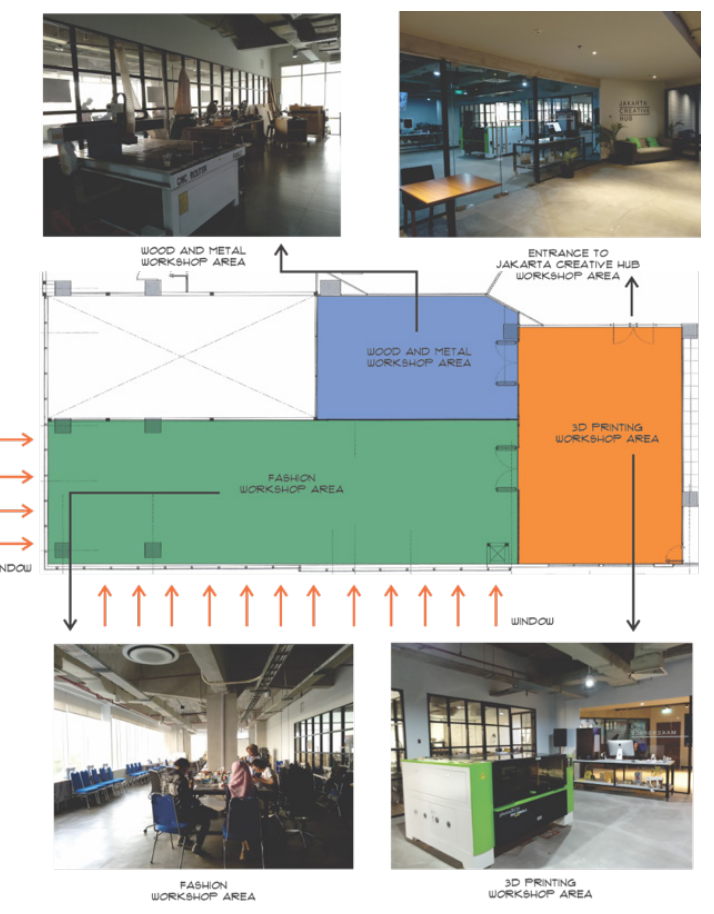

The fashion workshop area has two lighting sources, namely natural lighting from the sun entering through the window and artificial lighting from existing lights. Measurements were carried out at activity points in the fashion workshop area using Lux meter's light gauge to find out the level of light intensity in the fashion workshop area. Measurements are made three times in one day at 10.27 WIB, 13.05 WIB, and 16.00 WIB. Measurements were made three times to take samples of lighting intensity values in one day according to the operational time of the Jakarta Creative Hub itself, starting at 10:00 a.m. until 17:00 WIB. The results of measuring the intensity of light can be seen in the following figure:

Figure 4. Measurement results at 10.27

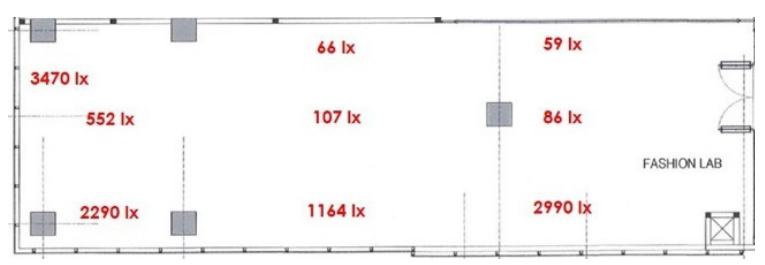


Journal of Architectural Research and Design Studies Volume 4 Number 1 April 2020

\section{5}

Figure 5. Measurement results at 13.05

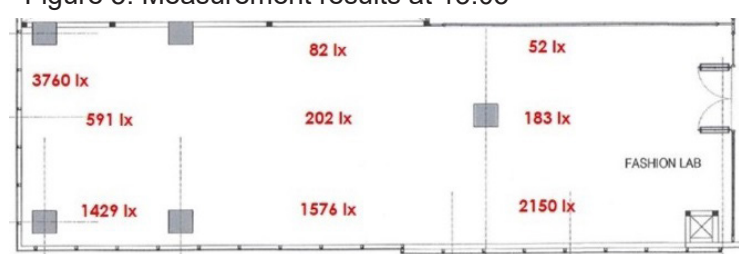

Figure 6. Measurement results at 16.00

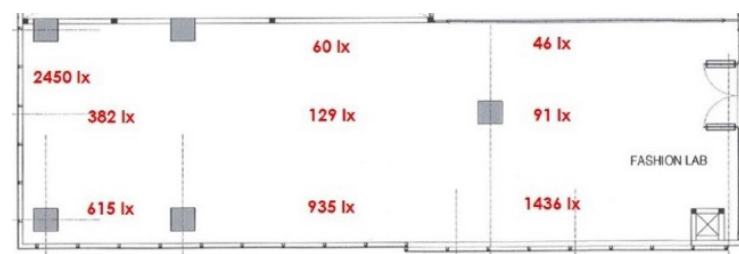

Figure 7. Measurements using Lux meter

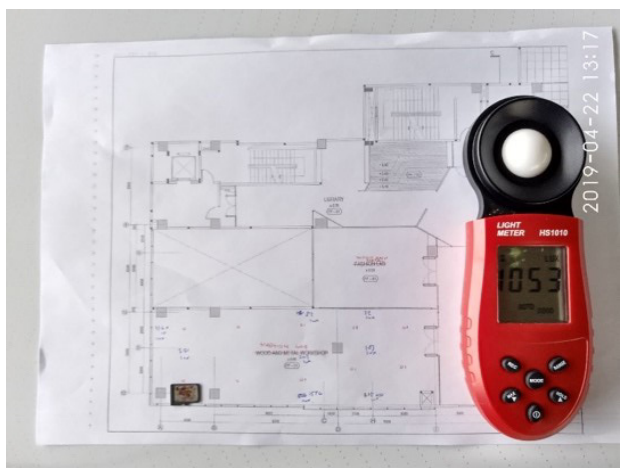

Data from the three measurement results indicate that in areas near natural light sources (windows) have a higher level of light intensity compared to distant points with natural light sources. When in use, the workshop area has been equipped with artificial lighting to increase the lighting intensity. When compared with Indonesian national standards for lighting in the industry, it requires a lighting intensity of 5001000 lux for space lighting used for fine work types. Then, the standard is compared with the results of direct measurements, which are obtained as follows:

\section{Lighting Standards}

Table 1. Table Comparison of Measurement Results with National Standards of Lighting for Workspace Areas / Workshops

\begin{tabular}{|c|c|c|c|c|c|}
\hline \multirow{3}{*}{$\begin{array}{l}\text { Lighting } \\
\text { Standards }\end{array}$} & \multirow{3}{*}{$\begin{array}{c}\text { Measurement } \\
\text { Point }\end{array}$} & \multicolumn{3}{|c|}{$\begin{array}{l}\text { Measurement time in } \\
\text { the Fashion Workshop } \\
\text { Jakarta creative hub }\end{array}$} & \multirow[t]{3}{*}{ Info } \\
\hline & & 10.27 & 13.05 & 16.00 & \\
\hline & & $\mathrm{AM}$ & PM & PM & \\
\hline \multirow{9}{*}{$\begin{array}{l}\text { Fine work } \\
500-1000 \\
\quad \text { lux }\end{array}$} & 1 & 59 & 52 & 46 & $x$ \\
\hline & 2 & 86 & 183 & 91 & $x$ \\
\hline & 3 & 2990 & 2150 & 1436 & 0 \\
\hline & 4 & 66 & 82 & 60 & $x$ \\
\hline & 5 & 107 & 202 & 129 & $x$ \\
\hline & 6 & 1164 & 1576 & 935 & 0 \\
\hline & 7 & 3470 & 3760 & 2450 & 0 \\
\hline & 8 & 552 & 591 & 382 & $x$ \\
\hline & 9 & 2290 & 1429 & 615 & 0 \\
\hline
\end{tabular}

Info :

$X=$ Does not meet standards

$\mathrm{O}=$ Meet the standards

From the table above, it can be seen that there are several points in this fashion workshop area that do not meet the minimum lighting standards for the work area for the type of fine work. Because from the existing artificial lighting according to the measurement results that are not enough to meet the needs of the lighting values needed, then the next step is to look for new artificial lighting design alternatives to meet the visual comfort in the workshop room. The alternative to the addition of artificial lighting was chosen because it was possible to implement the strategy compared to inserting natural lighting into the building, judging from the existing conditions of existing buildings.

By taking into account the results of light measurements and other types of artificial lighting consisting of General Lighting, Accent Lighting, Task Lighting, and Decorative Lighting, the modified lighting design strategies to be carried out are as follows. The workshop room area is an area for work, so the priority is the functionality of the lighting. Of the four types of lighting, namely General Lighting, Accent Lighting, Task Lighting, and Decorative Lighting, General Lighting's lighting type was chosen. General lighting is used to provide lighting evenly throughout the workshop area so that there are no dark parts. Thus, the 
circulation or road in the room can be seen clearly. The value for the intensity of General Lighting is attempted to approach the stated standard lighting value, which is a minimum of 500 lux.

Simulation is done to find lighting design according to the artificial lighting strategy above. Simulation is done with Dialux software with lamp data of 26 Watts with a power of 2037 lumen. The simulation results and plan for placement of the light points can be seen in the following figure:

Figure 9. Artificial Lighting Simulation with Dialux Software to achieve a value of 500 lux in the Jakarta Creative Hub Fashion Workshop Room

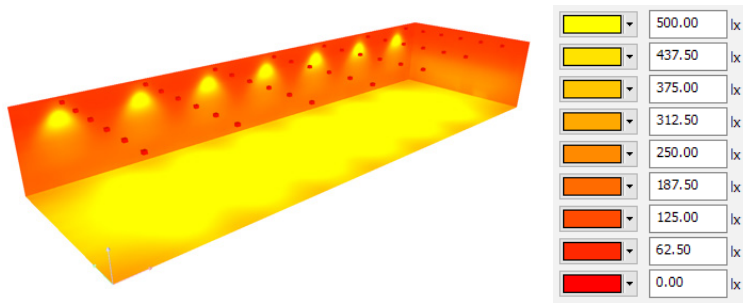

Figure 10. Artificial Lighting Simulation Results with Dialux Software at the Jakarta Creative Hub Fashion Workshop Room

Room 1 / Single Sheet Output
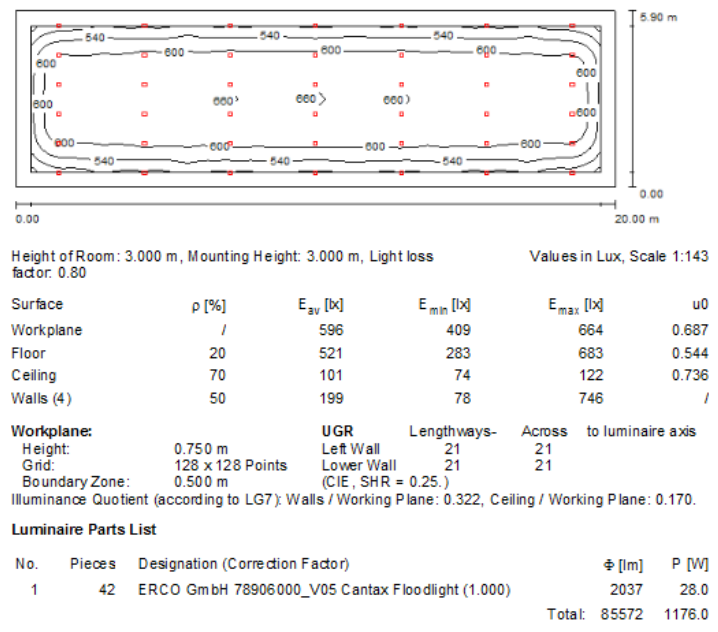

Specific conne ced load: $9.97 \mathrm{~W} / \mathrm{m}^{2}=1.67 \mathrm{~W} / \mathrm{m}^{2} / 100 \mathrm{Wx}$ (Ground area: $118.00 \mathrm{~m}^{2}$ )

From the simulation results, it can be seen that to get them evenly distributed 500 lux results, 42 light points are needed with the power of each lamp of 2037 lumens. From the simulation results above, it can meet the standard of light requirements required in the Indonesian National Standard for rooms with fine work types of 500 lux. The placement of light points configuration can still adjust to the types of activities that exist as long as they can be covered in the scope of the illumination of the lights.

\section{CONCLUSION}

From the results of measurements and lighting simulations found that:

1. The result of lighting intensity measurements for areas close to the window produces higher lighting intensities compared to areas far from the window. It proves that the distance to the source of the light affects the light intensity in a room.

2. There is a significant difference in light intensity between the area close to the window and the area far from the window. The area near the window exceeds the required lighting intensity for the workspace area, while the area far from the window is below the required lighting intensity for the workspace. The standard intensity of workspace lighting for fine work types based on the Indonesian National Standard is 500100 lux. The intensity of lighting for areas close to the workspace ranges between 1500-3500 lux, while the intensity of lighting for areas far from windows ranges from $40-$ 380 lux.

3. The intensity of lighting needed is evenly distributed lighting with an intensity of 5001000 lux. For areas near the window that have more than the required lighting intensity can be reduced by the use of sun shading in the form of curtains that can be adjusted to the natural lighting conditions at that time. This is to avoid glare that can occur due to excessive light entering the room.

4. For areas far from windows that have less than the required lighting, intensity can be added to artificial lighting. The proposed artificial lighting is in the form of general lighting, which can be adjusted according to the natural lighting conditions at that time. From the simulation using Dialux, the lights needed amounted to 42 lamps with the power of each lamp totaling 2037 lumens. A total of 42 lights are needed to produce evenly lit 596 lux in the workplace area, for a room with no natural lighting at all. This simulation is done with the limitation that the color, texture, and material of the room are considered default or not taken into account in the simulation process.

5. For rooms where there is natural lighting, such as the case in the Jakarta Creative Hub Fashion Workshop area, the proposed 
lighting strategy is a combination of natural and artificial lighting. For areas near the window, it is recommended to use sun shading in the form of curtains and for areas far from the window can be using artificial lighting. For evenly distributed lighting results, the total number of lamps recommended to have is 42 lamps with a strength of 2037 lumens provided that the lamps are divided into at least two zones, namely the point of the light near the window and the point of light far from the window. When the weather is very sunny, all lights can not be turned on. If the weather conditions are a little cloudy, the light in an area far from the window can be turned on, the lights near the window are not turned on. If the weather conditions are cloudy or if the room is used at night, all lights can be turned on. To reach the efficiency and effectiveness of the lighting intensity to be achieved between 500-1000 lux.

\section{References}

Ardiyanto, B., Utami, S. S., \& Ridwan, M. K. (2014). Analisis Kualitas Pencahayaan Menggunaakan Pemodelan Numeris Sesuai SNI Pencahayaan, Data Pengukuran Langsung (On-Site) dan Simulasi. TEKNOFISIKA, 63-71.

Frick, H., Ardiyanto, A., \& Darmawan, A. (2008). Ilmu Fisika Bangunan. Yogyakarta: Kanisius.

Hadianto, J., Sumartono, \& Nilasari, P. F. (2013). Pengaruh Pencahayaan Buatan Terhadap Kenyamanan Visual Pengunjung Pada Interior Boutique Banana Republik di Surabaya. JURNAL INTRA, 1-9.

Handoko, Y. (n.d.). Retrieved from https:// repository.unikom.ac.id/: https://repository. unikom.ac.id/30979/1/bab\%203\%20 pencahayaan\%20alami.pdf

Karyono, T. H. (2016). Arsitektur Tropis : Bentuk, Teknologi, Kenyamanan dan Penggunaan Energi. Jakarta: Penerbit Erlangga.

Latifah, N. L. (2015). Fisika Bangunan 1. Jakarta: Griya Kreasi.

Latifah, N. L. (2015). Fisika Bangunan 2. Jakarta: Griya Kreasi.

Latifah, N. L., Anugrah, D. A., Ayunani, M. D., \& Garini, K. W. (2013). Kajian Sistem Pencahayaan yang Mempengaruhi Kenyamanan Visual pada Ruang A dan Ruang Sayap Galeri Selasar Sunaryo. Reka Karsa, 1(3), 2.
Lechner, N. (2007). Heating, Cooling, Lighting Metode Desain untuk Arsitektur. Jakarta: Raja Grafindo Persada.

Manurung, P. (2012). Pencahayaan Alami Dalam Arsitektur. Yogyakarta: Penerbit ANDI.

Nasional, B. S. (2017). Retrieved from http:// iaeeta.org/: http://iaeeta.org/wp-content/ uploads/2017/08/sni-03-6197-2000Pencahayaan.pdf

Padmanaba, C. G. (2006). Pengaruh Penerangan Dalam Ruang Terhadap Produktivitas Kerja Mahasiswa Desain Interior. Dimensi Interior, 57-63.

Rahmadiina, F., Adhitama, M. S., \& Thojib, J. (2017). Optimalisasi Kinerja Pencahayaan Alami pada Kantor (Studi Kasus : Plasa Telkom Blimbing Malang). Student Journal Universitas Brawijaya.

Setiawan, A. (2013). Optimasi Distribusi Pencahayaan Alami Terhadap Kenyamanan Visual Pada Toko "OEN" di Kota Malang. JURNAL INTRA, 1-10.

Setiawan, B., \& Hartanti, G. (2014). Pencahayaan Buatan Pada Pendekatan Teknis Dan Estetis Untuk Bangunan dan Ruang Dalam. HUMANIORA, 1222-1233.

Soegandhi, S. J., Indrani, H. C., \& Dora, P. E. (2015). Optimasi Sistem Pencahayaan Buatan Pada Budget Hotel di Surabaya. JURNAL INTRA, 45-56.

Sushanti, A. B., Thojib, J., \& Asikin, D. (2015). Pengaruh Fasade Bangunan Terhadap Pencahayaan Alami Pada Laboratorium Politeknik Negeri Malang. Student Journal Universitas Brawijaya.

Sutantri, Thojib, J., \& Martiningrum, I. (2015). Kenyamanan Visual Gedung Pamer Pusat Seni Dan Kerajinan Kendedes Kabupaten Malang. Student Journal Universitas Brawijaya.

Thojib, J., \& Adhitama, M. S. (2013). Kenyamanan Visual Melalui Pencahayaan Alami Pada Kantor (Studi Kasus Gedung Dekanat Fakultas Teknik Universitas Brawijaya Malang). Jurnal RUAS, 10-15.

Widiyantoro, H., Muladi, E., \& Vidiyanti, C. (2017). Analisis Pencahayaan Terhadap Kenyamanan Visual Pada Pengguna Kantor (Studi Kasus: Kantor PT. Sandimas Intimitra Divisi Marketing di Bekasi). Vitruvian, 65-70.

Widiyananto, E. (n.d.). Retrieved from www. scribd.com: https://www.scribd.com/ doc/268998237/Kuliah-9-KenyamananVisual 